\title{
DETECTION OF A RARE BLOOD GROUP “BOMBAY (OH PHENOTYPE)” IN A POST CAESAREAN PREGNANCY WITH ANAEMIA - A RARE CASE REPORT FROM EASTERN INDIA
}

Anindya Kumar Das ${ }^{1}$, Swapan Das², Debjani Deb³, Prakash Das ${ }^{4}$, Subrata Gayen ${ }^{5}$

\section{HOW TO CITE THIS ARTICLE:}

Anindya Kumar Das, Swapan Das, Debjani Deb, Prakash Das, Subrata Gayen. "Detection of a rare blood group "Bombay (oh phenotype)" in a post caesarean pregnancy with anaemia - a rare case report from eastern India". Journal of Evolution of Medical and Dental Sciences 2013; Vol. 2, Issue 41, October 14; Page: 7959-7962.

ABSTRACT: The Bombay blood group is a very rare blood group discovered almost 60 years back. We report here, a high risk case of Post Caesarean pregnancy with anaemia with Bombay Blood Group.

KEYWORDS: High risk pregnancy, Post C.S, Anaemia, Bombay blood group.

INTRODUCTION: The blood group serology plays an important role in transfusion medicine. The discovery of a rare blood group, Bombay (Oh) Phenotype by Bhende et al in 1952 in Mumbai formerly (Bombay) was important in the field of immunohematology. The discovery later helped Watkins and Morgan ${ }^{1}$ (1959) and Gerard et $\mathrm{al}^{2}$ (1982) to elucidate biosynthetic pathway for ABH and Lewis (Le) antigens suggesting the secretor (Se) and (H) are closely linked structural genes. Recently, molecular genetic studies were carried out to determine the role of the $\mathrm{H}$, Se and Le genes in the expression of $\mathrm{H}$ antigen in secretions and Lewis blood group antigen on erythrocytes. 3.4 .

It is known that the precursor protein from which all blood groups are formed is termed as the " $\mathrm{H}$ " Antigen. This ' $\mathrm{H}$ ' antigen either translates into ' $\mathrm{A}$ ' antigen (blood group A) or into 'B' Antigen (blood group $B$ ) or into both $A$ and $B$ Antigens (blood group $A B$ ) or it remains as ' $\mathrm{H}$ '(blood group ' $O$ ').In the case of Bombay blood group, there is absence of ' $\mathrm{H}$ ' Antigen itself. Therefore ' $A$ ', ' $B$ ', 'AB' and ' $\mathrm{O}$ ' which are all different manifestations of ' $\mathrm{H}$ ' are alien to persons with Bombay blood group. The Bombay blood group is termed 'Oh' meaning absence of ' $\mathrm{H}$ ' Antigen.

CASE REPORT: A 25 year old Post C.S. $2^{\text {nd }}$ gravidae, at term pregnancy was referred from Purulia District Hospital and admitted in our hospital through emergency. The patient gave history of irregular antenatal checkup and did not consume iron folate tablets. Her menstrual history was normal. Her previous pregnancy and caesarean section were uneventful with no previous history of blood transfusion. There was no family history of Thalassemia or blood transfusion.

On examination the patient was severely anaemic ( $\mathrm{Hb}-4.5 \mathrm{gm} \%)$ with tachycardia and pedal oedema of lower limbs. Her blood pressure was 110/68 mm Hg Obstetric examination revealed full term post caesarean pregnancy with longitudinal lie, cephalic presentation, F.H.S.-146/min, regular with mild uterine contraction. Per vaginal examination suggested that she was in early labour.

Immediate decision for blood transfusion and termination of pregnancy by LUCS was taken. The blood was sent for grouping and cross matching to our Blood Bank where she was diagnosed to have the Bombay Blood group after reverse grouping. As this group is very rare, we could not find a single unit of this group in Bankura district and immediate blood transfusion could not be performed. Ultimately, after 4hours of admission, LUCS was performed without blood. After emergency caesarean section the first 72 hours were uneventful. On the $4^{\text {th }}$ post-operative day, the 
patient developed impending heart failure. Physician was consulted and treated accordingly. After stabilization of her condition she was referred to an urban tertiary medical college in Kolkata as no blood was available in this district or blood banks of the neighbouring districts.

DISCUSSION: The Bombay Oh Phenotype is more common in the western and southern parts of India as compared to the other states 5 .Out of the 179 cases reported by Sathe et al6(1988) from the Institute of Immunohematology (formerly blood group reference Centre, Bombay),112 cases $(62.6 \%)$ cases belonged to Maharashtra. The incidence of Bombay phenotype is high in those states of India where consanguineous marriages are more prevalent i.e. Andhra Pradesh, Karnataka, Tamil $\mathrm{Nadu}$, Maharashtra, Gujarat than the other states in India. Outside India, it is mostly confined to the South-East Asian countries ${ }^{5}$.

H-deficient Bombay phenotype is rare since it occurs in about 1 in 10,000 individuals in India and 1 per 1,000,000 in Europe 4 .

The mutational analysis has revealed that a person of the Bombay blood group carries homozygous recessive ('hh') genotype instead of homozygous dominant ('HH') or heterozygous ('Hh') genotype of ABO blood group. So ' $\mathrm{H}$ ' Antigen is not expressed on the RBC surfaces. The $\mathrm{h}$ allele is result of mutation of the $\mathrm{H}$ gene (FUT I) that expresses H Antigen on RBC's of ABO blood group. Bombay phenotypes are homozygous (hh) for T725G mutation (Leucine is changed to Arginine) in the FUT I coding region with gene deletion of FUT2.The consequence of this mutation is production of an inactivated enzyme that is incapable of producing ' $\mathrm{H}$ ' Antigen 7,8. After the first report of 'Oh' Phenotype from Mumbai, several other workers detected this peculiar phenotype in India 9,10.as well as in European countries ${ }^{11,12}$. Later on it was found that many of the European cases which were initially labeled as typical Bombay phenotypes, turned out to be para Bombay phenotypes after absorption elution studies. 5,13,14,15

To label and diagnose a case as typical Bombay Phenotype certain specialized tests like absorption-elution studies, titration of naturally occurring antibodies at different temperatures, inhibition of anti-H by $\mathrm{O}$ saliva secretor and secretor status were performed as described by Bhatia 1977.16,17 The difficulty with Bombay 'Oh' Phenotype is that a person having such a blood group can receive blood from an individual of Bombay phenotype only and no other blood will match in case of an emergency for blood transfusion.

CONCLUSION: Detection of Bombay blood group requires proper blood grouping and cross matching of the blood samples. This group would be categorized as the " 0 " group as it does not show any reaction to anti-A and anti- $\mathrm{B}$ antibodies just like normal ' $\mathrm{O}$ ' group. When cross matching with ' $\mathrm{O}$ ' group is done, then it would show cross reactivity or incompatibility. Therefore reverse grouping or serum grouping has to be done to detect this group.

As the Bombay blood group is a rare blood group, it is desirable to develop cryopreservation facilities for rare blood donor units. Every blood bank should maintain a rare blood type donor file with the help of Emergency obstetric care (EmOC) services so as to arrange blood in times of obstetric need and prevent maternal mortality. 


\section{REFERENCES:}

1. Watkins WM, Morgan WTJ 1959. Possible genetical pathways for the biosynthesis of blood group mucopolysaccharides. Vox Sang, 4: 97-119.

2. Gerard G, Vitrac D, Le Pendu J, Muller A, Oriol R 1982. H-deficient blood groups (Bombay) of Reunion Island. Am J Hum Genet, 34: 937-947.

3. Kaneko M, Nishihara S, Shinya N, Kudo T, Iwasaki H, Seno T, Okubo Y, Narimatsu H 1997. Wide variety of point mutations in the $\mathrm{H}$ gene of Bombay and para-Bombay individuals that inactivate H enzyme. Blood, 90: 839-849.

4. Oriol R, Candelier JJ, Mollicone R 2000. Molecular genetics of H. Vox Sang, 78 Suppl 2 105108

5. Balgir RS 2005.Detection of a Rare blood Group, "Bombay (Oh) Phenotype" Among the Kutia Kondh Primitive Tribe of Orissa, India. Int J Hum Genet. 5(3):193-198.

6. Sathe M, Vasantha K, Mhaisalkar P, Gorakshakar A 1988, Distribution of Bombay (Oh) phenotypes in India. J Indian Anthrop Soc, 23: 277-280.

7. Koda Y, Soejima M, Johnson DH, Smart E, Kimura H. Missense mutation of FUTI and detection of FUT2 are responsible for Indian Bombay Phenotype of ABO blood group system. Biochem Biophys Res Commun:1997;238:21-5.[Pub Med]

8. Fernandez-Mateos P, Cailleau A, Henry S, Costache M, Elmgren A, Svensson L, Larson G, Samuelsson BE, Oriol R, Mollicone R 1998. Point mutations and deletion responsible for the Bombay H null and the Reunion H weak blood groups. Vox Sang, 75: 37-46

9. Simmons RT, D’senna GWL 1955. Anti-H in group O blood. J Indian Med Assocn, 24: 325-332

10. Roy MN, Dutta S, Mitra PC, Ghosh S 1957. Occurrence of natural anti-H in a group of individuals. J Indian Med Assocn, 29: 224-226

11. Alosia M, Gelb AG, Fundenberg H, Hamper J, Tippett P and Race RR 1961. The expected Bombay groups Oh A1 and Oh A2. Transfusion, 1: 212-217.

12. Aust CH, Hocker ND, Keller ZG and Arbogast JL 1962. A family of Bombay blood type with suppression of blood group substance A1. Am J Clin Path, 37: 579-583.

13. Levine P, Robinson E, Celano M, Briggs O, Falkinburg L 1955. Gene interaction resulting in suppression of blood group substance B. Blood, 10: 1100-1108.

14. Lanset S, Ropartz C, Rouseau P, Guerbet Y, Salmon C 1966. Une familie comportant les phenotypes Bombay Oh AB et OhB. Transfusion (Paris), 9: 255-263

15. Bhatia HM, Solomon JM 1967. Further observations on Ahm and Ohm phenotypes. Vox Sang, 13: 457-460.

16. Bhatia HM 1977. Procedures in Blood Banking and Immuno-hematology. Mumbai: Blood Group Reference Centre (ICMR).

17. Balgir RS, Sharma JC 1988. Genetic markers in the Hindu and Muslim Gujjars of Northwestern India. Am J Phys Anthrop, 75: 391-403. 


\section{AUTHORS:}

1. Anindya Kumar Das

2. Swapan Das

3. Debjani Deb

4. Prakash Das

5. Subrata Gayen

\section{PARTICULARS OF CONTRIBUTORS:}

1. Professor, Department of Obstetrics and Gynaecology, Bankura Sammilani Medical College \& Hospital, Bankura.

2. RMO and Clinical Tutor, Department of Obstetrics and Gynaecology, Bankura Sammilani Medical College \& Hospital, Bankura.

3. Assistant Professor, Department of Obstetrics and Gynaecology, Bankura Sammilani Medical College \& Hospital, Bankura.
4. Post Graduate Trainee, Department of Obstetrics and Gynaecology, Bankura Sammilani Medical College \& Hospital, Bankura.

5. Assistant Professor, Department of Obstetrics and Gynaecology, Bankura Sammilani Medical College \& Hospital, Bankura.

\section{NAME ADDRESS EMAIL ID OF THE}

\section{CORRESPONDING AUTHOR:}

Dr. Anindya Kumar Das,

Nirmal Danga, Bankura,

PIN - 722101.

Email: akdas2007@rediffmail.com

Date of Submission: 01/10/2013.

Date of Peer Review: 02/10/2013.

Date of Acceptance: 05/10/2013.

Date of Publishing: 10/10/2013 